Sains Malaysiana 47(11)(2018): 2741-2755

http://dx.doi.org/10.17576/jsm-2018-4711-17

\title{
Ficus carica and Bone Health: A Systematic Review
}

(Ficus carica dan Kesihatan Tulang: Suatu Kajian Sistematik)

\begin{abstract}
RUSZYMAH BT HJ IDRUS*, NUR QISYA AFIFAH VERONICA SAINIK, AYU SURAYA ANSARI, MOHAMED S. ZULFARINA, RABIATUL ADAWIYAH RAZALI, ABID NORDIN, AMINUDDIN BIN SAIM \& ISA NAINA-MOHAMED
\end{abstract}

\begin{abstract}
Ficus carica, a native plant to the Middle East and Western Asia, is of high value in folk medicine. The therapeutic potential of Ficus carica has led to the extensive studies in recent years, focusing on evaluating and validating its pharmacological effect. The present systematic review summarizes the effectiveness of Ficus carica on promoting bone health focusing on osteoporosis and rheumatoid arthritis via mineral contents and RANKL pathway. The search was done with Medline via Ebscohost, Scopus and Google Scholar databases to obtain relevant articles published between 1946 and December 2016. The main inclusion criteria were research articles published in English that reported effect of Ficus carica on bone health. The literature search returned 716 potentially relevant articles, whereby 5 met the inclusion criteria. This systematic review concludes Ficus carica plays an important role in the promotion of bone health and can be a potential pharmaceutical product in the future.
\end{abstract}

Keywords: Bone; Ficus carica; osteoporosis; RANKL pathway; rheumatoid arthritis

ABSTRAK

Ficus carica ialah tumbuhan asli di Timur Tengah dan Asia Barat mempunyai kepentingan dalam perubatan tradisi. Potensi terapeutik Ficus carica telah membawa kepada kajian mendalam tertumpu kepada pengesahan kesan farmakologinya. Kajian sistematik ini mendalami keberkesanan Ficus carica dalam membantu kesihatan tulang yang memfokus kepada penyakit osteoporosis dan 'reumatoid artritis' melalui kandungan mineralnya dan laluan RANKL. Carian makalah telah dibuat menggunakan pangkalan data Medline melalui Ebscohost, Scopus dan Google Scholar untuk mendapatkan makalah berkaitan yang diterbitkan antara 1946 dan December 2016. Kriteria rangkuman utama untuk pemilihan makalah adalah penerbitan dalam Bahasa Inggeris yang melaporkan kesan Ficus carica kepada kesihatan tulang. Carian makalah menghasilkan 716 makalah yang berpotensi dengan 5 makalah menepati kriteria rangkuman. Kesimpulan kajian sistematik ini membuktikan bahawa Ficus carica memainkan peranan penting dalam membantu meningkatkan kesihatan tulang dan boleh dijadikan sebagai produk farmaseutik yang berpotensi pada masa hadapan.

Kata kunci: Ficus carica; laluan RANKL; osteoporosis; reumatoid artritis; tulang

\section{INTRODUCTION}

Ficus carica or commonly known as fig is a flowering plant belongs to the Moraceae family. It is one of the largest genera of angiosperms with more than 800 species of trees, epiphytes, and shrubs identified in the tropical and sub-tropical regions worldwide (Vinson 1999). It is known to be one of the earliest fruits cultivated in history (Singh et al. 2011). Ficus carica has been extensively studied for medicinal uses, which justifies its potential therapeutic value (Khairuddin et al. 2017; Mawa et al. 2013; Moniruzzaman et al. 2017). A report done by Gilani et al. (2008) showed that the fruit, root and leaves of Ficus carica are used in complementary medicine in different disorders such as spasm, respiratory disorders, inflammatory, gastrointestinal disorders and cardiovascular disorders.

The therapeutic potential of Ficus carica has led to the extensive studies in recent years, focusing on evaluating and validating its pharmacological effect. Ficus carica has been reported to possess antioxidant activity (Feng \& Ma 2010; Prabavathy \& Nachiyar 2011), anti-angiogenic activity, anticancer activity (Rubnov et al. 2001), antibacterial activity (Aref et al. 2010; Jeong et al. 2009; Mavlonov et al.2008), cytotoxicity activity (Khodarahmi et al. 2011), anticonstipation activity (Lee et al. 2012), hepatoprotective activity (Gond et al. 2008; Mohan et al. 2007), antihelmintic activity (Amol et al. 2010; Chandrashekhar et al. 2008), anti-inflammatory activity (Patil et al. 2011), antimutagenic activity (Agaberli et al. 2005), antipyretic activity (Patil et al.2010), antispasmodic activity (Gilani et al. 2008), antiplatelet activity (Gilani et al. 2008), hypoglycemic activity (El- Shobaki et al. 2010; Perez et al. 1996), hypolipidimic activity (Asadi et al. 2006), antiviral activity (Lazreg Aref et al. 2011) and immunostimulant activity (Patil et al. 2010).

Fruits such as olive (Chin \& Ima-Nirwana 2016) and pomegranate (Shuid \& Mohamed 2013) as an alternative 
dietary supplementation for osteoporosis have been suggested for individual who preferred vegan diet or those who have medical condition that prevents them from consuming dairy or meat product such as milk allergy.

Mineral content of fig has been reported to closely resemble that of human milk, with iron being the most important. The iron content in Ficus carica is also said to be 50\% as much as that of beef liver (Lydia 2009). In plant eating bird, Ficus carica has been reported to be the choice for dietary source of calcium by O'Brien et al. (1998). Together, their findings suggested the potential of Ficus carica as an alternative dietary supplement for prevention of osteoporosis.

Bone problem such as bone loss, osteoporosis and rheumatoid arthritis are a global health problem. Aging can reduce bone mineral density (BMD), eventually leading to osteoporosis. Dairy products with high level of calcium are recommended to be consumed in order to promote and maintain BMD level, especially in the elderly. Apart from being nutritional source of minerals, Ficus carica has also been reported to modulate bone remodelling (Choi et al. 2011; Park et al.2009). The mechanism of bone remodeling is composed of a balance between bone resorption phase regulated by osteoclast and bone formation phase regulated by osteoblast (Liu et al. 2010; Raggatt et al. 2010). The imbalance of bone remodeling process caused by an excessive differentiation of osteoclast cells has been previously reported, that can lead to bone lytic diseases, such as osteoporosis and rheumatoid arthritis (Park et al. 2008).

The activation of osteoclasts is known to be regulated by two cytokines; receptor activator of nuclear factor- $\kappa \beta$ ligand (RANKL) and macrophage colony-stimulation factor (M-CSF). The binding of RANKL to its receptor RANK on the surface of osteoclast, leads to the activation of TNF receptorassociated factor 6 (TRAF6), which is linked to nuclear factor kappa-light-chain-enhancer of activated B cells $(\mathrm{NF}-\kappa \mathrm{B})$ via mitogen-activated protein kinases (MAPKs). RANKL and M-CSF are proteins secreted by osteoblasts and is important for the formation of osteoclast and regulation of its activity (Boyce \& Xing 2008).

Studies led by Choi et al. (2011) and Park et al. (2009), respectively, have showed that Ficus carica can act as a potent inhibitor of osteoclastogenesis in receptor activator of nuclear factor kappa-B ligand (RANKL) pathway and regulates expression of osteoblast specific genes such as bone morphogenetic protein 2 (BMP-2), osteoprotegerin (OPG) and osteocalcin (OCN). The importance of RANKL signaling mechanism in bone remodelling is well established (Liu et al. 2010; Raggatt et al. 2010). Both studies suggested that Ficus carica may potentially provide a novel therapy for bone disorder such as osteoporosis (Choi et al. 2011; Park et al. 2009).

In this review, studies reporting the beneficial effect of Ficus carica on bone health via its high mineral contents and its potential to inhibit osteoclastogenesis will be discussed.

\section{METHODS}

\section{SEARCH STRATEGY}

A systematic review of the literature was conducted to identify relevant studies reporting the effects of Ficus carica on bone health. Two databases were searched in regard to this, Medline via Ebscohost and Scopus (both published between 1946 and December 2016) and Google Scholar (no limitation in search). The search strategy involved a combination of the following sets of key words; Ficus carica AND osteo* OR rheum* OR bone*.

\section{INCLUSION AND EXCLUSION CRITERIA}

The results were limited only to the studies published in English language due to limited resources for translation services. Primary literature with research focus on Ficus carica effects on bone health was included. Review articles, news, letter, editorials or case studies were excluded from the review. Study not related to Ficus carica effects on bone health were removed.

\section{DATA EXTRACTION AND MANAGEMENT}

Articles were screened prior to their inclusion in this review. Titles and abstracts were screened first to ensure inclusion and exclusion criteria were adhered. In the final phase, the remaining papers were read thoroughly and the data extracted. The following data were recorded from the studies: the types of study; aims of study; subject or sample; methods; result; and remarks or conclusion. All the data extraction and management were re-evaluated by two independent reviewers to validate the data integrity.

\section{RESULTS}

\section{LITERATURE SEARCH}

The literature identified several relevant articles. All the articles were assessed for inclusion or exclusion based on the title and abstract. The search yielded 716 articles, of which 5 articles met the inclusion criteria. All data were extracted directly from the articles. A flow chart of the selection and paper process including reasons for exclusion is shown in Figure 1. Further details on each study regarding methodological and outcome aspects were summarized in Table 1.

\section{EVALUATION OF MAJOR MINERAL CONTENTS OF FICUS CARICA CRUCIAL FOR BONE HEALTH}

Three studies were included in this review to evaluate the mineral contents of Ficus carica that is crucial for bone health (Khan et al. 2011; Sadia et al. 2014; Soni et al. 2014). Khan et al. (2011) was the earliest to conduct physicochemical profiling of Ficus carica (Sadia et al. 2014). Their findings showed that their fig samples contain high amount of potassium $(\mathrm{K})$ at $382.4-611.5 \mathrm{mg} / 100 \mathrm{~g}$. This is followed by magnesium $(\mathrm{Mg})$ at $110.50-202.40$ 


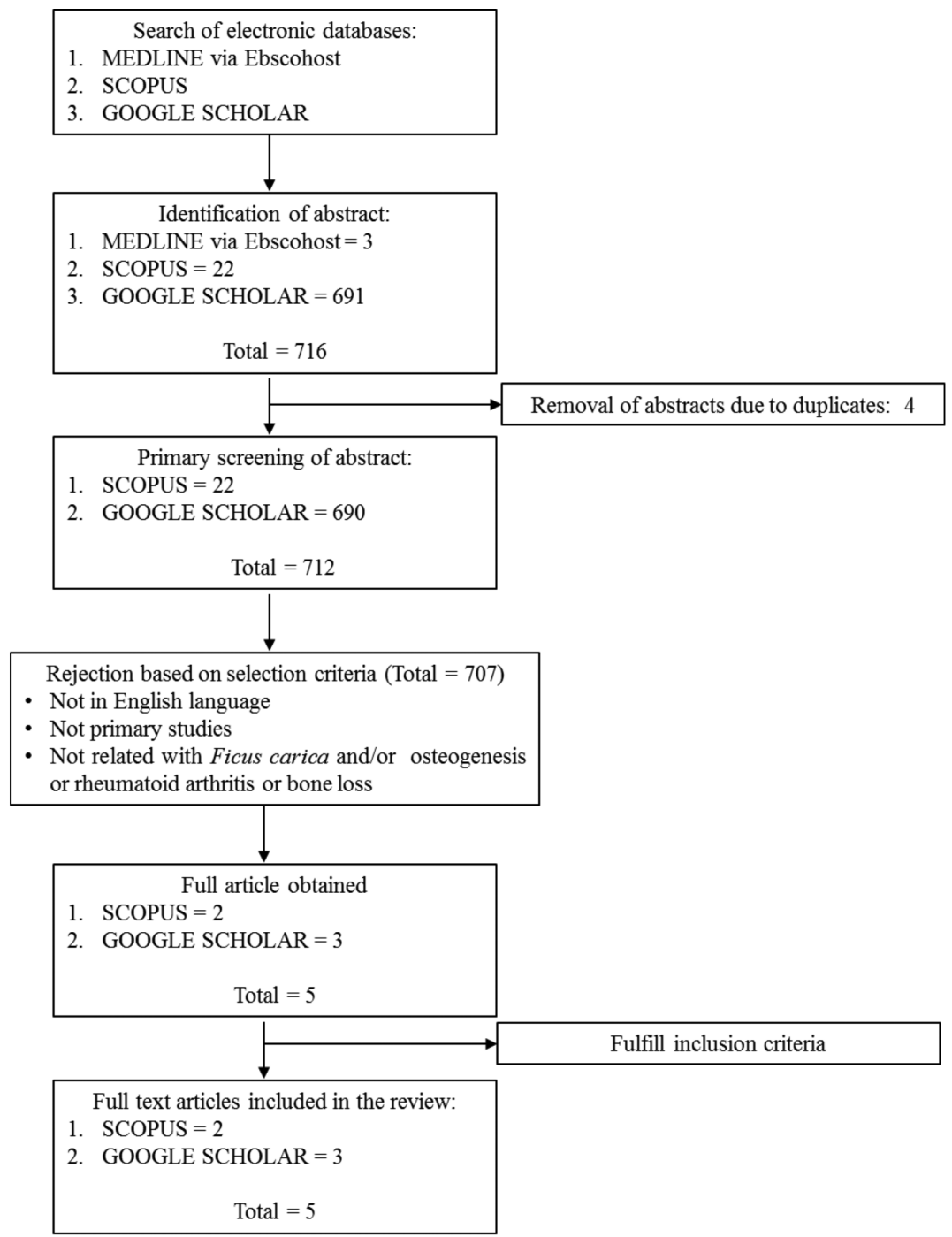

FIGURE 1. Flow chart of the search strategy, study selection and data management procedure

$\mathrm{mg} / 100 \mathrm{~g}$, Calcium (Ca) 78.72-132.80 mg/100 g and phosphorous (P) at 31.91-76.96 $\mathrm{mg} / 100 \mathrm{~g}$ (Khan et al. 2011). They suggested that the minerals found in Ficus carica fruit are essential for bone growth and maintenance.

Sadia et al. (2014) has led a study to evaluate the physicochemical characteristics of a few species of underutilized figs and mulberries. It showed that the dried figs extract contains higher concentration of trace elements such as potassium $(\mathrm{K})$, magnesium $(\mathrm{Mg})$, calcium $(\mathrm{Ca})$, phosphorus (P) and Iron (Fe) [31]. Accordingly, Ficus carica was reported to have the highest level of $\mathrm{Ca}$ ((10.94 $\pm 2.75) \mathrm{mg} / \mathrm{g}$ dry weight) among all the fruits tested (Sadia et al. 2014).

This is in agreement to another study led by Soni et al. (2014) that reported dried fig to be a very good source of minerals like Strontium ( $\mathrm{Sr}$ ), $\mathrm{Ca}, \mathrm{Mg}, \mathrm{P}$ and Fe (Soni et al. 2014). They found that Strontium has the highest amount in fig (saturated) while the level of $\mathrm{Ca}, \mathrm{Mg}, \mathrm{P}$ and $\mathrm{Fe}$ to be relatively high at $1545.46,679.04,365.75$ and $29.49 \mathrm{ppm}$, respectively. Strontium and calcium in dried fig has been found to contribute towards good bone health (Soni et al. 2014). In terms of nutritional profile, fig have carbohydrates as a major component $(73.50 \%)$, high energy value $(317.78 \mathrm{kcal})$, very low amount of fat $(0.56 \%)$, moderate amount of protein $(4.67 \%)$, dietary fiber content $(3.68 \%)$, found to contain moisture (16.63\%) and high ash content (4.65\%) (Soni et al. 2014).

\section{EFFECT OF FICUS CARICA ON MOLECULAR MECHANISM OF BONE HEALTH}

Studies led by Choi et al. (2011) and Park et al. (2009) have successfully linked Ficus carica to the molecular mechanism of bone formation via the RANKL signaling. In the first study, Choi et al. (2011) tested the effect of four types of long chain polyunsaturated fatty acids (PUFAs) from Ficus carica, namely E-DHA, DHA, EDA (cis-11, 14-eicosadienoic acid) and EPA on the osteogenesis parameters of RAW264.7 murine macrophages and preosteoblastic MC3T3-E1 cells.

In terms of RAW 264.7 cells, E-DHA was found to be a much more potent inhibitor of RANKL-induced osteoclastogenesis (Choi et al. 2011). TRAP staining showed 


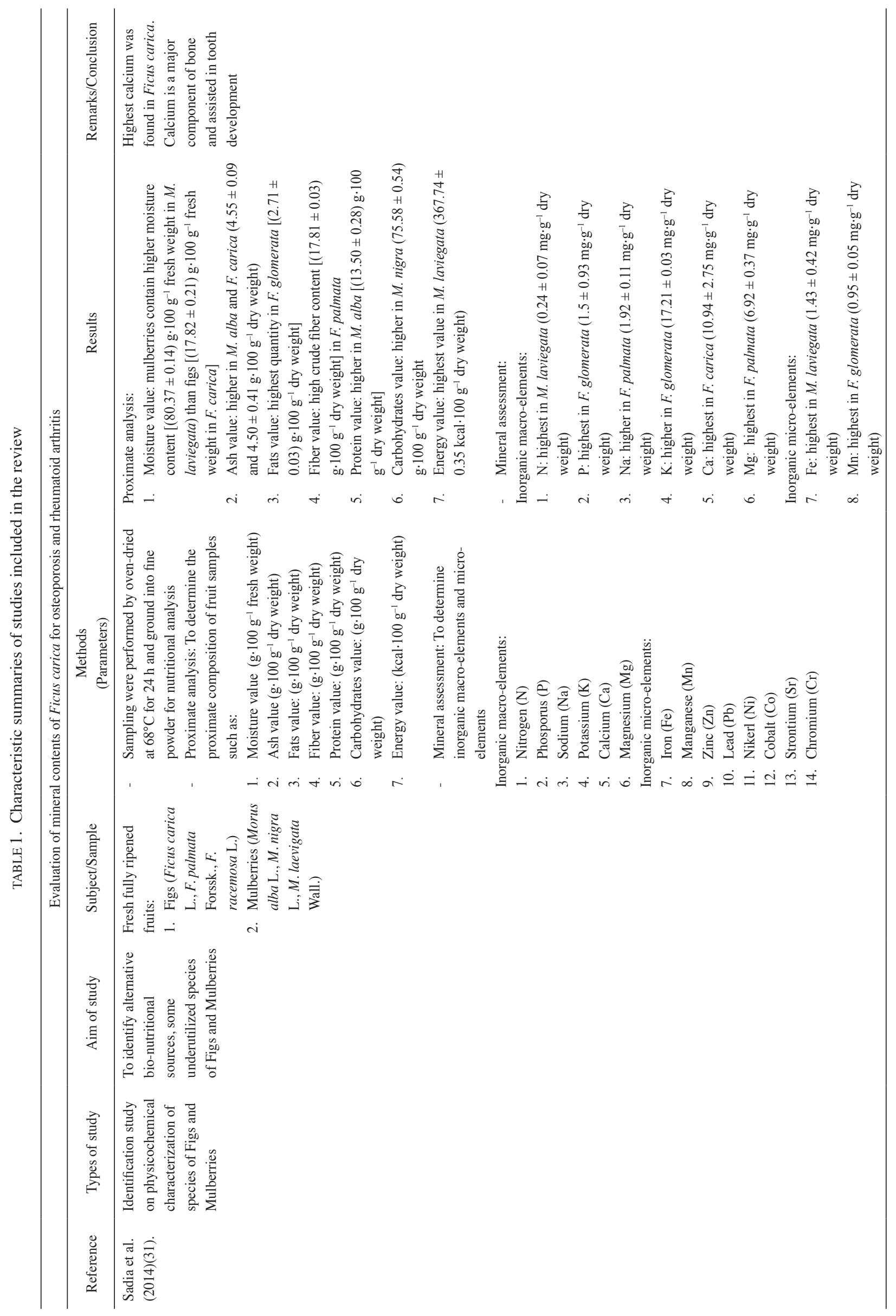




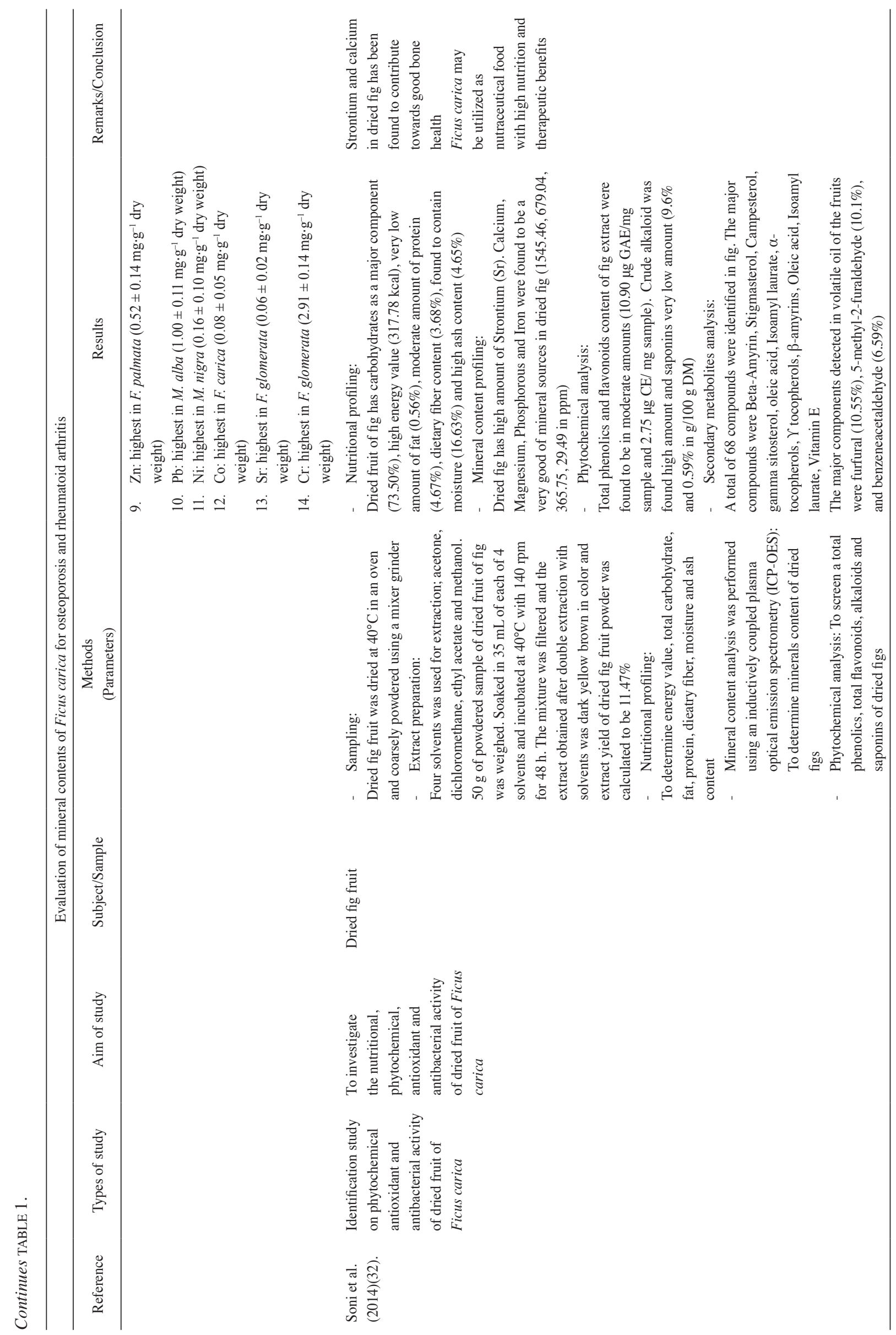




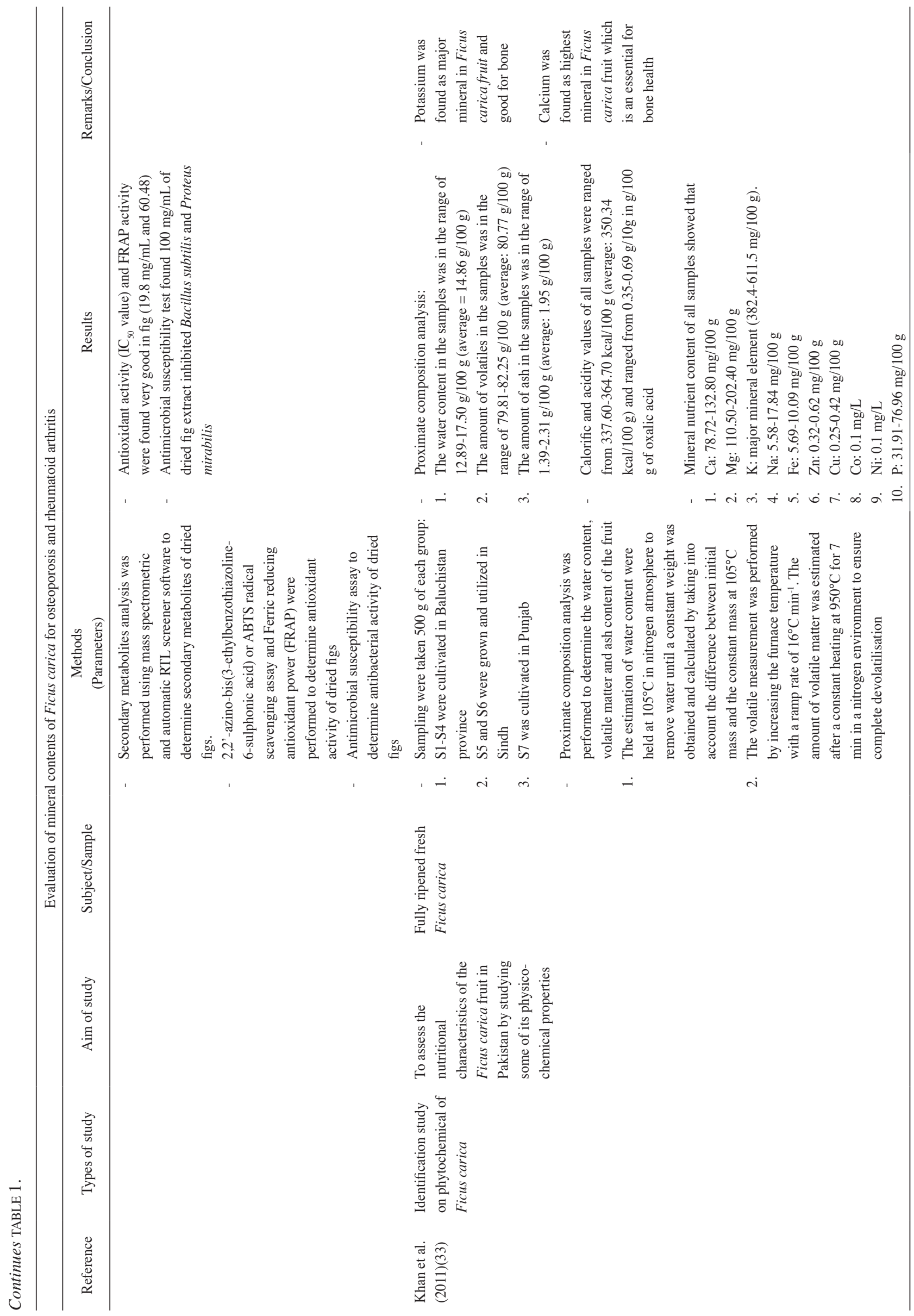




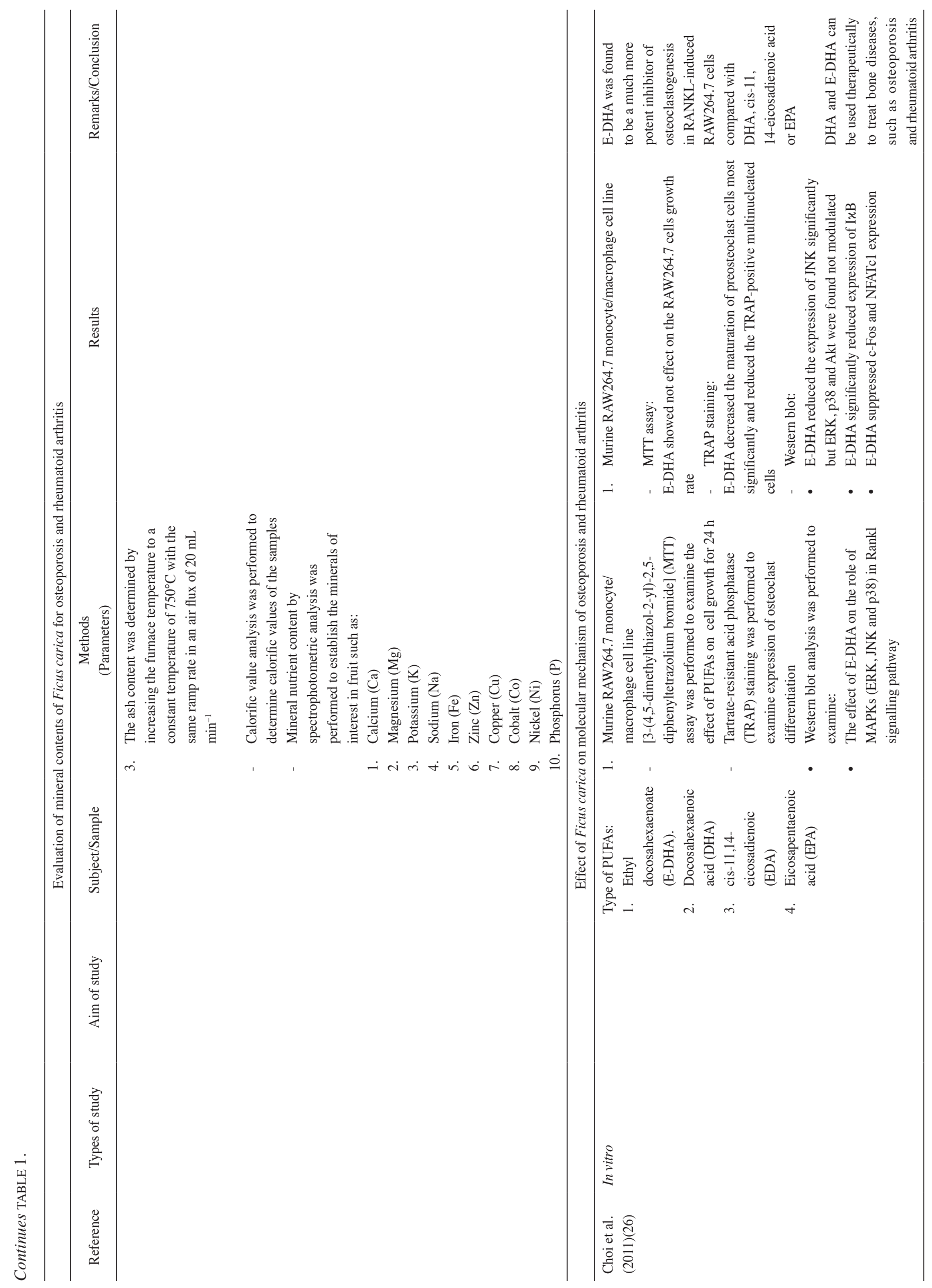




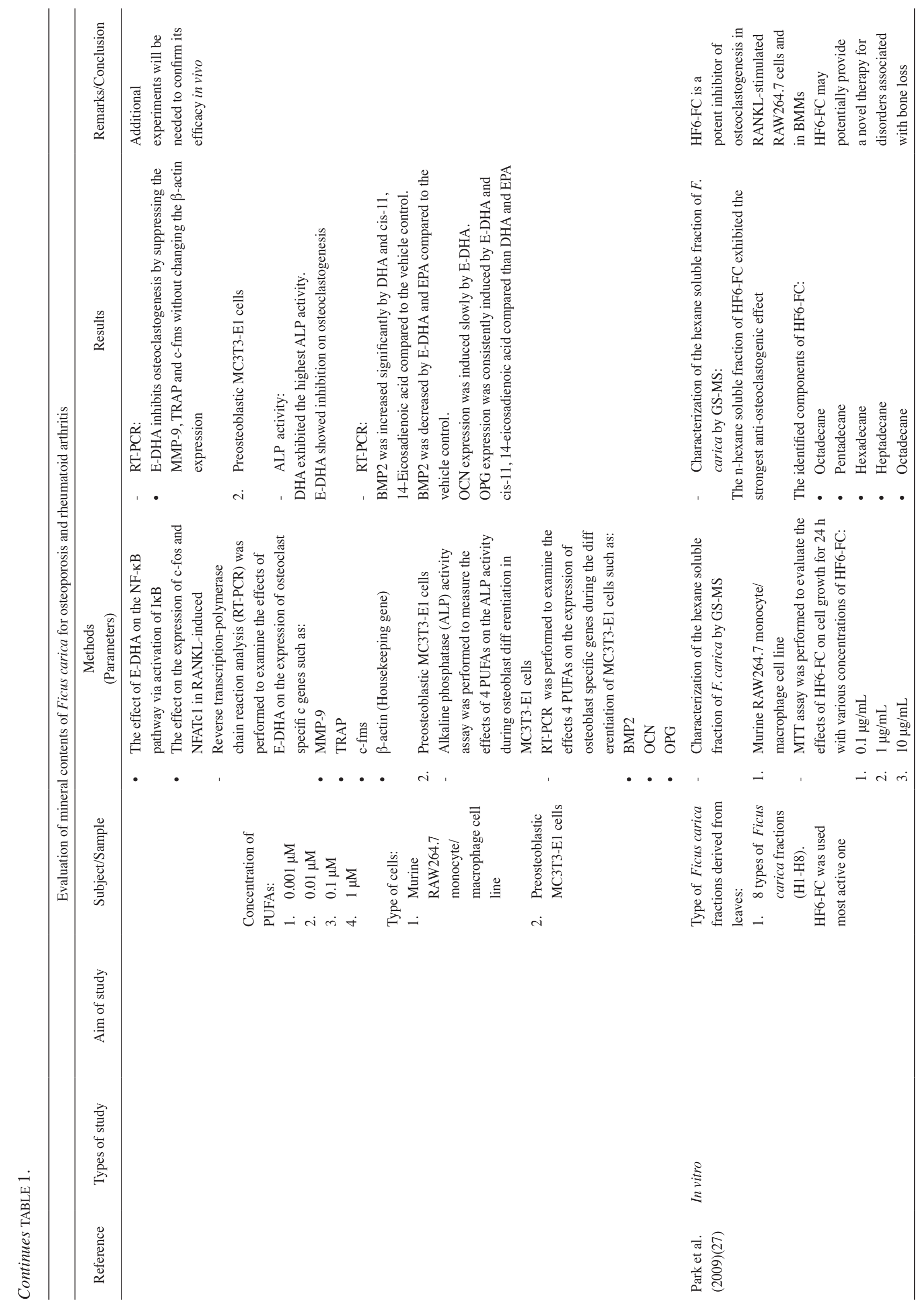




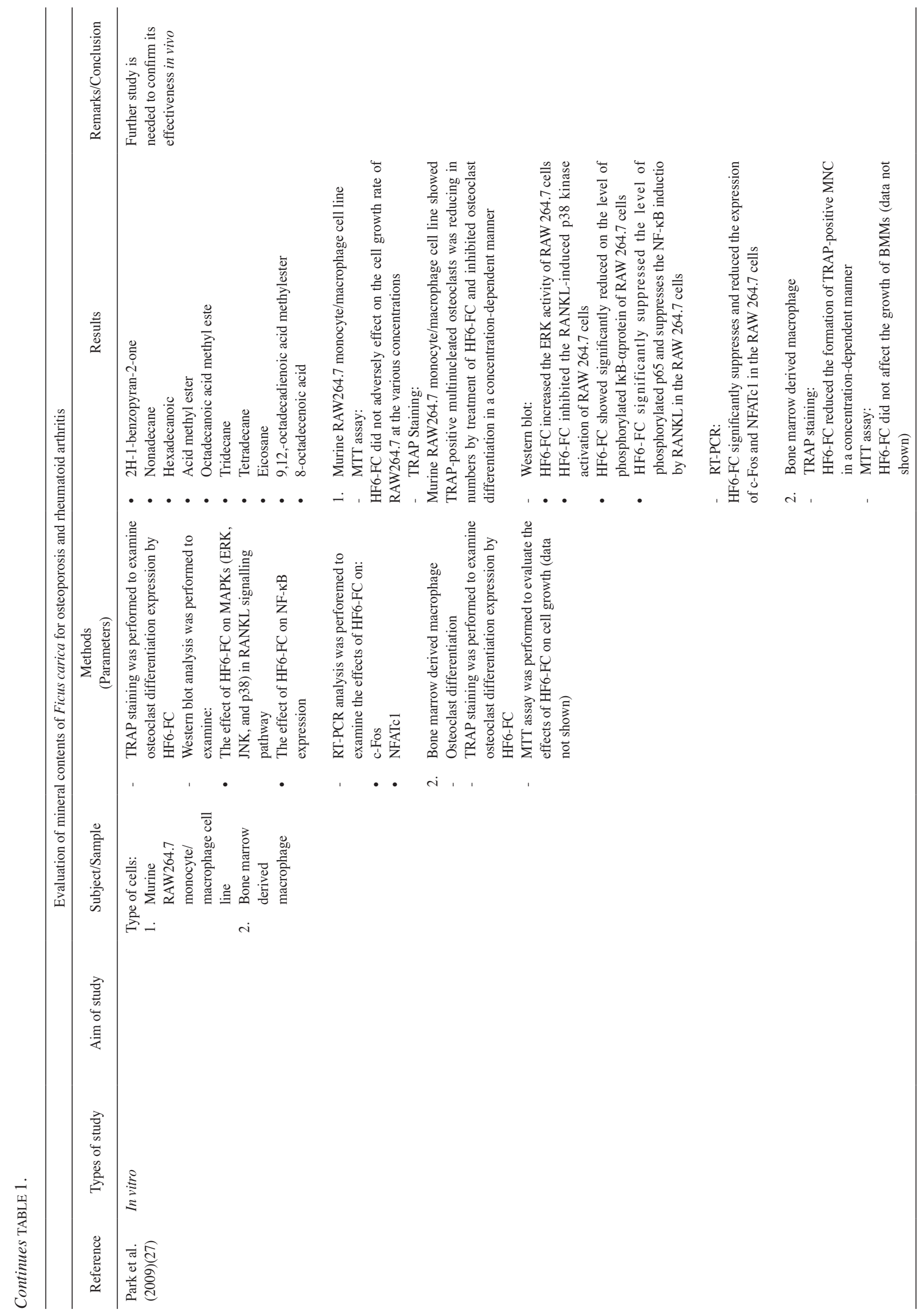


that the E-DHA decreased the maturation of preosteoclast cells most significantly and reduced the TRAP-positive multinucleated cells in RAW264.7 cells (Choi et al. 2011). E-DHA showed no effect on the RAW264.7 cells growth rate evaluated through MTT assay after $24 \mathrm{~h}$ treatment (Choi et al. 2011). Western blot results showed that the E-DHA significantly reduced the expression of c-Jun NH2-terminal kinases (JNK) (Choi et al. 2011). In contrast, the extracellular signal-regulated kinase (ERK), p38 mitogen-activated protein kinases (p38) and protein kinase B (Akt) were not modulated. Treatment of E-DHA in RAW264.7 cells also significantly reduced the expression of IkappaB kinase (IкB) and suppressed c-Fos and NFATc1 expression. In addition, the increased RANKL-induced level of c-fos mRNA was reversed by E-DHA in a concentration-dependent manner. Finally, the mRNA expression of MMP-9, TRAP and c-fms was also suppressed following the treatment of E-DHA. Overall, the data suggested the inhibition of osteoclastogenesis in RAW264.7 cells by E-DHA (Choi et al. 2011). Treatment of DHA on preosteoblastic MC3T3-E1 cells has been shown to promote the highest ALP activity in vitro. However, after treatment of E-DHA in preosteoblastic MC3T3-E1 cells, osteoclastogenesis was inhibited. RT-PCR results showed that osteogenic markers such as BMP2 was increased significantly by DHA and EDA but decreased by E- DHA and EPA in preosteoblastic MC3T3-E1 cells. Expression of OCN was induced slowly by E-DHA compared to other PUFAs. OPG expression was consistently induced by E-DHA and cis-11, 14-eicosadienoic acid not by DHA and EPA (Choi et al. 2011).

An earlier study done by Park et al. (2009) was conducted to assess the effects of the hexane soluble fraction of Ficus carica leaf (HF6-FC) on RANKL-induced osteoclastogenesis in murine monocytes/macrophage RAW264.7 cells and bone marrow-derived macrophages (BMMs). In this study, they determined eight types of Ficus carica fractions (HF1-HF8), but only HF6-FC was the most active for all the parameters.

They showed that the n-hexane soluble fraction of HF6-FC exhibited the strongest anti-osteoclastogenic effect. They optimized the extraction method and identified components of HF6-FC which are octadecane, pentadecane, hexadecane, heptadecane, octadecane, 2H-1-benzopyran-2-one, nonadecane, hexadecanoic, acid methyl ester, octadecanoic acid methyl este, tridecane, tetradecane, eicosane, 9,12,-octadecadienoic acid methylester and 8-octadecenoic acid (Park et al. 2009).

Their sample of bone marrow-derived macrophages (BMMs) was obtained from mice tibia and femur bone marrow and MTT assay was performed to evaluate the effect of HF6- FC on the cell growth rate of RAW264.7 and BMMs at the various concentrations. The MTT showed that the HF6-FC did not adversely affect both cells. Osteoclast cells derived from BMM were successfully differentiated and cultured in medium containing M-CSF (30 ng/ $\mathrm{mL})$ and RANKL (200 ng/mL). The effect of HF6-FC on osteoclastogenesis in murine monocyte/macrophage RAW
264.7 cells was evaluated via TRAP staining. Treatment of HF6-FC on both cells showed a reduction in the numbers of TRAP-positive multinucleated osteoclasts indicating inhibited osteoclast differentiation in a concentrationdependent manner (Park et al . 2009). Western blot analysis showed that the HF6-FC increased the ERK activity of RAW 264.7 cells. In contrast, the HF6-FC inhibited the RANKLinduced p38 kinase activation by significantly reducing the level of phosphorylated IкB- $\alpha$ protein of RAW 264.7 cells. These suggested that the HF6-FC significantly suppressed the level of phosphorylated p65 and the NF- $\mathrm{\kappa B}$ induction by RANKL in the RAW 264.7 cells. Reverse transcriptionpolymerase chain reaction analysis was performed to examine the effects of HF6-FC on expression of c-Fos and NFATc1 in the RAW 264.7 cells. The result showed that HF6-FC significantly suppresses expression of c-Fos and NFATc1 in the RAW 264.7 cells (Park et al. 2009).

\section{DISCUSSION}

In the present review, major mineral contents of Ficus carica, namely potassium (K), magnesium $(\mathrm{Mg})$, calcium (Ca), phosphorus (P) and Strontium (Sr) were found to be crucial for strong bone development (Khan et al. 2011; Sadia et al. 2014; Soni et al. 2014). Calcium and magnesium is a major component in bone and tooth development (Brody \& Bender 1994; Reid et al. 1993; Rude et al. 2004). Potassium is a blood pressure controlling mineral and reported calcium-potassium may also neutralize increased urinary calcium loss and helping to prevent bones from thinning out at a fast rate (Cozzolino et al. 2001).

Interestingly, Strontium has been shown to improve bone health (Marie 2005; Reginster et al. 2007). Clinical studies done by Reginster et al. (2007) reported the effect of Strontium ranelate (PROTELOS $®$ ) was found to reduce vertebral and non-vertebral fractures in osteoporosis subjects. Strontium ranelate (PROTELOS $®$ ) is an oral drug for postmenopausal osteoporosis, has been reported to decrease bone resorption and to stimulate bone formation. Moreover, their finding showed that the figs is a promising source of protein, carbohydrate, fibers and vitamins, with high energy values.

Moverover, our sytematic review on molecular evaluation of Ficus carica showed that studies done by Choi et al. (2011) and Park et al. (2009) were focused on the effect of Ficus carica extract on RANKL signalling pathway which is very important for bone remodelling in bone loss and arthritis (Figure 2) (Choi et al. 2011; Park et al. 2009). Jimi et al. (2004) demonstrated that bone destruction and inflammation are closely linked in diseases via inhibition of NF-KB lead to block osteogenesis and prevent inflammatory bone destruction in vivo. Similar results with several studies done by Coon et al. (2007), Han et al. (2007), Mino et al. (1998) and Teitelbaum and Ross (2003), showed that the osteoclast development, involvement of inflammatory cytokines and the signalling pathway of RANKL are important in bone remodelling. 


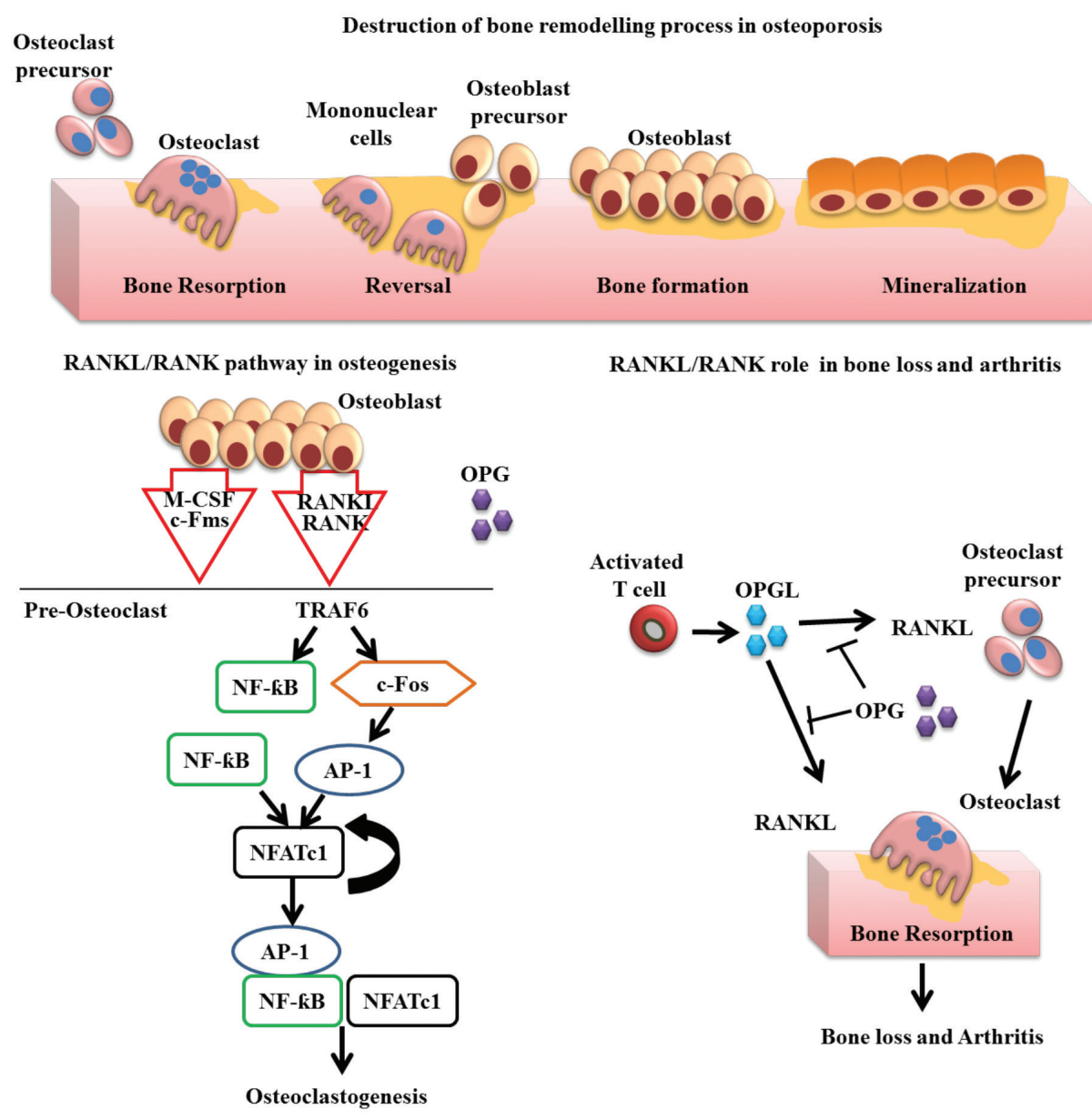

FIGURE 2. Schematic diagram destruction of bone remodelling process in osteoporosis, involving RANKL/RANK pathway

Osteoclast differentiation from monocyte/ macrophage precursor cells is controlled by two currently known factors, macrophage colony-stimulation factor (M-CSF) and receptor activator of nuclear factor $\kappa \mathrm{B}$ (NF-KB) ligand (RANKL) (Theill et al. 2002; Zhao et al. 2007). M-CSF and RANKL are two important cytokines that involved in osteoclastogenesis (Theill et al. 2002). The osteoblasts will secrete M-CSF to provide the survival of precursor cell signaling (Yoshida et al. 1990). RANKL binding to its receptor RANK activates TNF receptorassociated factor 6 (TRAF6), which is linked to NF- $\mathrm{KB}$ and mitogen-activated protein kinases (MAPKs) (Kobayashi et al.2001; Lee et al. 2002). In addition, RANKL induces the key transcription factor for osteoclastogenesis, nuclear factor of activated T cell c1 (NFATc1) (Takayanagi et al. 2002).

In year 2005, Luo et al. showed that osteoblast lineage cells expressed a membrane bound form of RANKL after treatment with Ficus carica extract in vitro. The osteoblast precursor cell lineage, express a membrane bound form of RANKL, a member of the tumor necrosis factor (TNF) cytokine family and strongly activates the NF-кB pathway. Study done by Takayanagi et al. (2002) and Yamashita et al. (2007) reported that the binding of RANKL to its receptor RANK in bone marrow-derived macrophages (BMMs) recruits TNF receptor-associated factor 1 (TRAF) family proteins such as TRAF6, which play roles in interaction with NF- $\mathrm{KB}$ and c-Jun NH2-terminal kinases (JNK) pathways.

The canonical NF- $\kappa \mathrm{B}$ pathway involves the phosphorylation of the IkappaB kinase (IкB) kinase complex inhibitor caused by the ligation of RANK (Luo

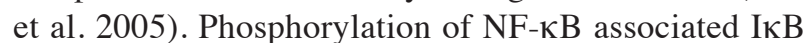
leads to its ubiquitination and proteosomal degradation. $\mathrm{I} \kappa \mathrm{B}$ is an enzyme complex that play role in propagating the cellular response to inflammation (Viatour et al. 2005). The transcription factor Nuclear factor of activated T- cells, cytoplasmic 1 (NFATc1), Tartrate-resistant acid phosphatase (TRAP), cathepsin K and Matrix metallopeptidase 9 (MMP-9), also plays a critical role in RANKL-induced osteoclastogenesis (Motyckova et al. 2001; Takayanagi et al. 2002). AP-1 and NF-אB binding sites were reported to be present within the promoter region of the NFATc1 gene, explaining the connection between NFATc1 and NF-кB (Zhou et al. 2002).

During osteoblast differentiation in bone remodelling, BMP-2 enhances osteoclast differentiation by upregulating the RANKL (Tachi et al. 2010). BMP-2, which belongs 
to the transforming growth factor- $\beta$ (TGF- $\beta$ ) super family, transduces its signal to the target bone genes such as alkaline phosphatase (ALP), bone sialoprotein, osteocalcin, Runt-related transcription factor 2 (RUNX2) and distal-less homeobox 5 (Dlx5) (Mukherjee et al. 2010; Tachi et al. 2010).

In this review we discussed that the E-DHA was found to be a much more potent inhibitor of osteoclastogenesis in RANKL-induced RAW264.7 cells than DHA, cis-11, 14eicosadienoic acid or EPA done by Choi et al. (2011). Moreover, the E-DHA may exert its inhibitory effect by suppressing the JNK and NF- $\mathrm{KB}$ signalling pathways which correlated with the MMP-9, c-fms and TRAP expression. Interestingly, Choi et al. (2011) reported that the DHA strongly induced osteoblast differentiation in MC3T3-E1 and these results supported that a DHA diet induces bone formation but does not inhibit bone resorption in animal experiments. In vitro study done by Rahman et al. (2008) also reported that the effects of mixed fatty acid supplements with different DHA contents on bone mass by inhibition the RANKL- induced differentiation of osteoclasts from RAW264.7 cells after DHA treatment.

However in vivo study done by Poulsen et al. (2007), reported the inhibitory effects of DHA on mature osteoclasts might be minimal or transient because no effect of DHA on bone resorption was observed in growing male rats or in ovariectomized (OVX) female rats. They also reported a significantly increase in bone formation or a change in the site of bone formation.

Park et al. (2009) reported that HF6-FC inhibited $\mathrm{NF}-\kappa \mathrm{B}$ transcriptional activity, phosphorylation of I $\mathrm{B}$ and $\mathrm{p} 65$. The involvement of these transcription factor and kinases in RANKL induced osteogenesis is well established. RANKL has been reported to activates extracellular signal-regulated kinases (ERK), JNK and Mitogen-Activated Protein Kinase p38 (p38) in osteoclasts and their precursor cells in NF- $\mathrm{KB}$ pathways (Chang et al. 2007; Kobayashi et al. 2001; Lee et al. 2002; Yoshida et al. 1990). However, study done by Miyazaki et al. (2000) reported that in osteoclasts differentiation, ERK activity correlates with cell survival through the activation of c-Fos, JNK increases AP-1 transcriptional activity via c-Jun phosphorylation, but not with resorption function.

Interestingly, they also showed that HF6-FC inhibited the RANKL-induced p38 kinase activation, but HF6-FC did not inhibit the ERK activation. Moreover, they showed that the HF6-FC prolonged ERK activity, suggesting the pivotal role of HF6-FC in influencing osteoclast survival through ERK, while inhibiting osteoclastogenesis via p38 kinase. Accordingly, they reported that HF6-FC did not affect the expression of MMP9, TRAP, RANK and cathepsin $\mathrm{K}$ in RANKL-induced RAW 264.7 cells.

\section{STRENGTHS AND LIMITATIONS}

General positive outcomes were reported in all studies included. Availability of evidence in the literature specific to the application of fig on bone health is limited. Different parts of the Ficus plant were used by investigators of each study included in the review making the interpretation of its efficacy difficult.

\section{IMPLICATIONS FOR FUTURE RESEARCH}

In order to make strong conclusions about the claimed benefits of fig on promotion bone health, further studies could help to define the minimum effective dose of fig required for beneficial effects, the minimum effective duration of consumption or supplementation, as well as the best preparation of extract for maximal beneficial effect. However, given that the evidence to date does support some impact of fig on bone health.

\section{IMPLICATIONS FOR CLINICAL APPLICATION}

The impact in in vivo study is unknown. If there is proven beneficial effect of fig on bone health, more work has to be initiated in order to make Ficus carica as a useful supplement as well as treatment for bone diseases. Nevertheless, before this could be planned, concurrently the adverse effects of fig extract must be clearly evaluated.

\section{CONCLUSION}

This study showed that Ficus carica has beneficial effects on bone health due to its high minerals content and inhibition of osteoclastogenesis via RANKL pathway. Therefore, Ficus carica has a potential to be used as a pharmaceutical product for bone health.

\section{ACKNOWLEDGEMENTS}

The authors would like to thank the Library of Universiti Kebangsaan Malaysia Medical Centre, for providing access to the databases. This study is made possible by grants from the Amrus Medik Sdn Bhd. FF-2017-020.

\section{REFERENCES}

Agabeı̌li, R.A. \& Kasimova, T.E. 2005. Antimutagenic activity of Armoracia rusticana, Zea mays and Ficus carica plant extracts and their mixture. TSitologiia I Genetika 39(3): 75-79.

Amol, P.P., Vikas, V.P., Vijay, R.P. \& Rajesh, Y.C. 2010. Anthelmintic and preliminary phytochemical screening of leaves of Ficus carica Linn against intestinal helminthiasis. International Journal of Research in Ayurveda and Pharmacy (IJRAP) 1(2): 601-605.

Aref, H.L., Salah, K.B., Chaumont, J.P., Fekih, A., Aouni, M. \& Said, K. 2010. In vitro antimicrobial activity of four Ficus carica latex fractions against resistant human pathogens (antimicrobial activity of Ficus carica latex). Pakistan Journal of Pharmaceutical Science 23(1): 53-58.

Asadi, F., Pourkabir, M., Maclaren, R. \& Shahriari, A. 2006. Alterations to lipid parameters in response to fig tree (Ficus carica) leaf extract in chicken liver slices. Turkish Journal of Veterinary and Animal Sciences 30(3): 315-318. 
Boyce, B.F. \& Xing, L. 2008. Functions of RANKL/RANK/OPG in bone modeling and remodelling. Archives of Biochemistry and Biophysics 473(2): 139-146.

Brody, T. \& Bender, D.A. 1994. Nutritional biochemistry. Biotechnology and Applied Biochemistry 20(1): 147.

Chandrashekhar, C., Latha, K., Vagdevi, H. \& Vaidya, V. 2008. Anthelmintic activity of the crude extracts of Ficus racemosa. International Journal of Green Pharmacy 2(2): 100-103.

Chang, E.J., Kim, H.J., Ha, J., Kim, H.J., Ryu, J., Park, K.H., Kim, U.H., Lee, Z.H., Kim, H.M., Fisher, D.E. \& Kim, H.H. 2007. Hyaluronan inhibits osteoclast differentiation via Toll- like receptor 4. Journal of Cell Science 120(1): 166-176.

Chin, K.Y. \& Ima-Nirwana, S. 2016. Olives and bone: A green osteoporosis prevention option. International Journal of Environmental Research and Public Health 13(8): 755

Choi, B.Y., Eun, J.S., Nepal, M., Lee, M.K., Bae, T.S., Kim, B.I. \& Soh, Y.J. 2011. Ethyl docosahexaenoate and its acidic form increase bone formation by induction of osteoblast differentiation and inhibition of osteoclastogenesis. Biomolecules \& Therapeutics 19(1): 70-76.

Coon, D., Gulati, A., Cowan, C. \& He, J. 2007. The role of cyclooxygenase-2 (COX-2) in inflammatory bone resorption. Journal of Endodontics 33(4): 432-436.

Cozzolino, M., Dusso, A.S. \& Slatopolsky, E. 2001. Role of calcium-phosphate product and bone-associated proteins on vascular calcification in renal failure. Journal of the American Society of Nephrology 12(11): 2511-2516.

El-Shobaki, F.A., El-Bahay, A.M., Esmail, R.S.A., El-Megeid, A.A. \& Esmail, N.S. 2010. Effect of figs fruit (Ficus carica L.) and its leaves on hyperglycemia in alloxan diabetic rats. World Journal of Dairy \& Food Sciences 5(1): 47-57.

Feng, C. \& Ma, Y. 2010. Isolation and anti-phytopathogenic activity of secondary metabolites from Alternaria sp. FL25, an endophytic fungus in Ficus carica. Chinese Journal of Applied and Environmental Biology 16: 76-78.

Gilani, A.H., Mehmood, M.H., Janbaz, K.H., Khan, A.U. \& Saeed, S.A. 2008. Ethnopharmacological studies on antispasmodic and antiplatelet activities of Ficus carica. Journal of Ethnopharmacology 119(1): 1-5.

Gond, N.Y. \& Khadabadi, S.S. 2008. Hepatoprotective activity of Ficus carica leaf extract on rifampicin-induced hepatic damage in rats. Indian Journal of Pharmaceutical Sciences 70(3): 364-366.

Han, K.Y., Yang, D., Chang, E.J., Lee, Y., Huang, H., Sung, S.H., Lee, Z.H., Kim, Y.C. \& Kim, H.H. 2007. Inhibition of osteoclast differentiation and bone resorption by sauchinone. Biochemical Pharmacology 74(6): 911-923.

Jeong, M.R., Kim, H.Y. \& Cha, J.D. 2009. Antimicrobial activity of methanol extract from Ficus carica leaves against oral bacteria. Journal of Bacteriology and Virology 39(2): 97-102.

Jimi, E., Aoki, K., Saito, H., D’Acquisto, F., May, M.J., Nakamura, I., Sudo, T., Kojima, T., Okamoto, F., Fukushima, H. \& Okabe, K. 2004. Selective inhibition of NF-кB blocks osteoclastogenesis and prevents inflammatory bone destruction in vivo. Nature Medicine 10(6): 617-24.

Khairuddin, M., Haron, H., Yahya, H. \& Che Malek, N. 2017. Nutrient compositions and total polyphenol contents of selected dried fruits available in Selangor, Malaysia. Journal of Agricultural Science 9(13): 41-49.

Khan, M.N., Sarwar, A., Adeel, M. \& Wahab, M.F. 2011. Nutritional evaluation of Ficus carica indigenous to Pakistan. African Journal of Food, Agriculture, Nutrition and Development 11(5): 5187-5202.
Khodarahmi, G.A., Ghasemi, N., Hassanzadeh, F. \& Safaie, M. 2011. Cytotoxic effects of different extracts and latex of Ficus carica L. on HeLa cell line. Iranian Journal of Pharmaceutical Research: IJPR 10(2): 273.

Kobayashi, N., Kadono, Y., Naito, A., Matsumoto, K., Yamamoto, T., Tanaka, S. \& Inoue, J.I. 2001. Segregation of TRAF6-mediated signaling pathways clarifies its role in osteoclastogenesis. The EMBO Journal 20(6): 1271-1280.

Lazreg Aref, H., Gaaliche, B., Fekih, A., Mars, M., Aouni, M. Pierre Chaumon, J. \& Said, K. 2011. In vitro cytotoxic and antiviral activities of Ficus carica latex extracts. Natural Product Research 25(3): 310-319.

Lee, H.Y., Kim, J.H., Jeung, H.W., Lee, C.U., Kim, D.S., Li, B . Lee, G.H., Sung, M.S., Ha, K.C., Back, H.I. \& Kim, S.Y. 2012. Effects of Ficus carica paste on loperamide-induced constipation in rats. Food and Chemical Toxicology 50(3-4): 895-902.

Lee, S.E., Woo, K.M., Kim, S.Y., Kim, H.M., Kwack, K., Lee, Z.H. \& Kim, H.H. 2002. The phosphatidylinositol 3-kinase, p38, and extracellular signal-regulated kinase pathways are involved in osteoclast differentiation. Bone 30(1): 71-77.

Liu, C., Walter, T.S., Huang, P., Zhang, S., Zhu, X., Wu, Y., Wedderburn, L.R., Tang, P., Owens, R.J., Stuart, D.I. \& Ren, J. 2010. Structural and functional insights of RANKLRANK interaction and signaling. The Journal of Immunology 184(12): 6910-6919.

Luo, J.L., Kamata, H. \& Karin, M. 2005. IKK/NF-кB signaling: Balancing life and death-a new approach to cancer therapy. The Journal of Clinical Investigation 115(10): 2625-2632.

Lydia, D.E. 2009. Wonders of figs. In Summaries and Short Reviews. http:// www.shvoong.com/medicine-and-health/ nutrition/1866223-wonders-figs.

Marie, P.J. 2005. Strontium as therapy for osteoporosis. Current Opinion in Pharmacology 5(6): 633-636.

Mawa, S., Husain, K. \& Jantan, I. 2013. Ficus carica L. (Moraceae): Phytochemistry, traditional uses and biological activities. Evidence-Based Complementary and Alternative Medicine 2013: 974256

Mavlonov, G.T., Ubaidullaeva, K.A., Rakhmanov, M.I., Abdurakhmonov, I.Y. \& Abdukarimov, A. 2008. Chitinbinding antifungal protein from Ficus carica latex. Chemistry of Natural Compounds 44(2): 216-219.

Mino, T., Sugiyama, E., Taki, H., Kuroda, A., Yamashita, N., Maruyama, M. \& Kobayashi, M. 1998. Interleukin$1 \alpha$ and tumor necrosis factor $\alpha$ synergistically stimulate prostaglandin E2-dependent production of interleukin-11 in rheumatoid synovial fibroblasts. Arthritis \& Rheumatology 41(11): 2004-2013.

Miyazaki, T., Katagiri, H., Kanegae, Y., Takayanagi, H., Sawada, Y., Yamamoto, A., Pando, M.P., Asano, T., Verma, I.M., Oda, H. \& Nakamura, K. 2000. Reciprocal role of ERK and NF$\mathrm{\kappa B}$ pathways in survival and activation of osteoclasts. The Journal of Cell Biology 148(2): 333-342.

Mohan, G.K., Pallavi, E., Kumar, R., Ramesh, M. \& Venkatesh, S. 2007. Hepatoprotective activity of Ficus carica Linn leaf extract against carbon tetrachloride-induced hepatotoxicity in rats. DARU Journal of Pharmaceutical Sciences 15(3): 162-166.

Moniruzzaman, M., Yaakob, Z. \& Taha, R.A. 2017. In vitro production of fig (Ficus carica L.) plantlets. In 5th International Symposium on Fig. International Society for Horticultural Science. Acta Horticulturae 1173: 231-235. 
Motyckova, G., Weilbaecher, K.N., Horstmann, M., Rieman, D.J., Fisher, D.Z. \& Fisher, D.E. 2001. Linking osteopetrosis and pycnodysostosis: Regulation of cathepsin K expression by the microphthalmia transcription factor family. Proceedings of the National Academy of Sciences 98(10): 5798-5803.

Mukherjee, A., Wilson, E.M. \& Rotwein, P. 2010. Selective signaling by Akt 2 promotes bone morphogenetic protein 2-mediated osteoblast differentiation. Molecular and Cellular Biology 30(4): 1018-1027.

O'brien, T.G., Kinnaird, M.F., Dierenfeld, E.S., Conklin-Brittain, N.L., Wrangham, R.W. \& Silver, S.C. 1998. What's so special about figs? Nature 392(6677): 668.

Patil, V.V., Bhangale, S.C. \& Patil, V.R. 2010. Studies on immunomodulatory activity of Ficus carica. International Journal of Pharmaceutical Science 2(4): 97-99.

Patil, V.V. \& Patil, V.R. 2011. Evaluation of anti-inflammatory activity of Ficus carica Linn leaves. Indian Journal of Natural Products and Resources 2: 151-155.

Patil, V.V., Bhangale, S.C. \& Patil, V.R. 2010. Evaluation of antipyretic potential of Ficus carica leaves. Evaluation 2(2): 010.

Park, C.K., Lee, Y., Chang, E.J., Lee, M.H., Yoon, J.H., Ryu, J.H. \& Kim, H.H. 2008. Bavachalcone inhibits osteoclast differentiation through suppression of NFATc1 induction by RANKL. Biochemical Pharmacology 75(11): 2175-2182.

Park, Y.R., Eun, J.S., Choi, H.J., Nepal, M., Kim, D.K., Seo, S.Y., Li, R., Moon, W.S., Cho, N.P., Cho, S.D. \& Bae, T.S. 2009. Hexane-soluble fraction of the common fig, Ficus carica, inhibits osteoclast differentiation in murine bone marrowderived macrophages and RAW 264.7 cells. The Korean Journal of Physiology \& Pharmacology 13(6): 417-424.

Perez, C., Dominguez, E., Ramiro, J.M., Romero, A., Campillo, J.E. \& Torres, M.D. 1996. A study on the glycaemic balance in streptozotocin-diabetic rats treated with an aqueous extract of Ficus carica (fig tree) leaves. Phytotherapy Research 10(1): 82-83.

Poulsen, R.C., Firth, E.C., Rogers, C.W., Moughan, P.J. \& Kruger, M.C. 2007. Specific effects of $\gamma$-Linolenic, eicosapentaenoic, and docosahexaenoic ethyl esters on bone post- ovariectomy in rats. Calcified Tissue International 81(6): 459-471.

Prabavathy, D. \& Nachiyar, C.V. 2011. Screening and characterisation of antimicrobial compound from endophytic Aspergillus sp. isolated from Ficus carica. Journal of Pharmaceutical Research 4: 1935-1936.

Raggatt, L.J. \& Partridge, N.C. 2010. Cellular and molecular mechanisms of bone remodeling. Journal of Biological Chemistry 285(33): 25103-25108.

Rahman, M.M., Bhattacharya, A. \& Fernandes, G. 2008. Docosahexaenoic acid is more potent inhibitor of osteoclast differentiation in RAW 264.7 cells than eicosapentaenoic acid. Journal of Cellular Physiology 214(1): 201-209.

Reginster, J.Y., Malaise, O., Neuprez, A. \& Bruyère, O. 2007. Strontium ranelate in the prevention of osteoporotic fractures. International Journal of Clinical Practice 61(2): 324-328.

Reid, I.R., Ames, R.W., Evans, M.C., Gamble, G.D. \& Sharpe, S.J. 1993. Effect of calcium supplementation on bone loss in postmenopausal women. New England Journal of Medicine 328(7): 460-464.

Rubnov, S., Kashman, Y., Rabinowitz, R., Schlesinger, M. \& Mechoulam, R. 2001. Suppressors of cancer cell proliferation from fig (Ficus carica) resin: Isolation and structure elucidation. Journal of Natural Products 64(7): 993-996.
Rude, R.K., Gruber, H.E., Norton, H.J., Wei, L.Y., Frausto, A. \& Mills, B.G. 2004. Bone loss induced by dietary magnesium reduction to $10 \%$ of the nutrient requirement in rats is associated with increased release of substance $\mathrm{P}$ and tumor necrosis factor- $\alpha$. The Journal of Nutrition 134(1): 79-85.

Sadia, H., Ahmad, M., Sultana, S., Abdullah, A.Z., Teong, L., Zafar, M. \& Bano, A. 2014. Nutrient and mineral assessment of edible wild fig and mulberry fruits. Fruits 69(2): 159-166.

Shuid,A.N. \& Mohamed, I.N. 2013. Pomegranate use to attenuate bone loss in major musculoskeletal diseases: An evidencebased review. Current Drug Targets 14(13): 1565-1578.

Singh, D., Singh, B. \& Goel, R.K. 2011. Traditional uses, phytochemistry and pharmacology of Ficus religiosa: A review. Journal of Ethnopharmacology 134(3): 565-583.

Soni, N., Mehta, S., Satpathy, G. \& Gupta, R.K. 2014. Estimation of nutritional, phytochemical, antioxidant and antibacterial activity of dried fig (Ficus carica). Journal of Pharmacognosy and Phytochemistry 3(2): 158-165.

Tachi, K., Takami, M., Zhao, B., Mochizuki, A., Yamada, A., Miyamoto, Y., Inoue, T., Baba, K. \& Kamijo, R. 2010. Bone morphogenetic protein 2 enhances mouse osteoclast differentiation via increased levels of receptor activator of NF-кB ligand expression in osteoblasts. Cell and Tissue Research 342(2): 213-220.

Takayanagi, H., Kim, S., Koga, T., Nishina, H., Isshiki, M., Yoshida, H., Saiura, A., Isobe, M., Yokochi, T., Inoue, J.I. \& Wagner, E.F. 2002. Induction and activation of the transcription factor NFATc1 (NFAT2) integrate RANKL signaling in terminal differentiation of osteoclasts. Developmental Cell 3(6): 889-901.

Teitelbaum, S.L. \& Ross, F.P. 2003. Genetic regulation of osteoclast development and function. Nature Reviews Genetics 4(8): 638.

Theill, L.E., Boyle, W.J. \& Penninger, J.M. 2002. RANK-L and RANK: T cells, bone loss, and mammalian evolution. Annual Review of Immunology 20(1): 795-823.

Viatour, P., Merville, M.P., Bours, V. \& Chariot, A. 2005.

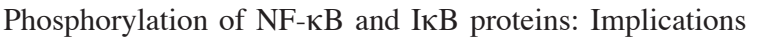
in cancer and inflammation. Trends in Biochemical Sciences 30(1): 43-52.

Vinson, J.A. 1999. The functional food properties of figs. Cereal Foods World 44(2): 82-87.

Yamashita, T., Yao, Z., Li, F., Zhang, Q., Badell, I.R., Schwarz, E.M., Takeshita, S., Wagner, E.F., Noda, M., Matsuo, K. \& Xing,L. 2007. NF-кB p50 and p52 regulate receptor activator of NF- $\mathrm{\kappa B}$ ligand (RANKL) and tumor necrosis factor-induced osteoclast precursor differentiation by activating c-Fos and NFATc1. Journal of Biological Chemistry 282(25): 1824518253.

Yoshida, H., Hayashi, S.I., Kunisada, T., Ogawa, M., Nishikawa, S., Okamura, H., Sudo, T., Shultz, L.D. \& Nishikawa, S.I. 1990. The murine mutation osteopetrosis is in the coding region of the macrophage colony stimulating factor gene. Nature 345(6274): 442.

Zhao, Q., Shao, J., Chen, W. \& Li, Y.P. 2007. Osteoclast differentiation and gene regulation. Frontier in Bioscience 12(1): 2519-2529.

Zhou, B., Cron, R.Q., Wu, B., Genin, A., Wang, Z., Liu, S., Robson, P. \& Baldwin, H.S. 2002. Regulation of the murine Nfatc1 gene by NFATc2. Journal of Biological Chemistry 277(12): 10704-10711. 
Ruszymah Bt Hj Idrus*, Nur Qisya Afifah Veronica Sainik, Ayu Suraya Ansari, Rabiatul Adawiyah Razali \& Abid Nordin Department of Physiology, Faculty of Medicine Universiti Kebangsaan Malaysia Medical Centre Jalan Yaacob Latif, Bandar Tun Razak 56000 Cheras, Kuala Lumpur, Federal Territory Malaysia

Aminuddin bin Saim

Ear, Nose \& Throat Consultant Clinic

Ampang Puteri Specialist Hospital 68000, Ampang, Selangor Darul Ehsan Malaysia
Mohamed S. Zulfarina \& Isa Naina-Mohamed

Pharmacoepidemiology Unit, Department of Pharmacology Faculty of Medicine

Universiti Kebangsaan Malaysia Medical Centre Jalan Yaacob Latif, Bandar Tun Razak

56000 Cheras, Kuala Lumpur, Federal Territory Malaysia

*Corresponding author; email: ruszyidrus@gmail.com

Received: 1 February 2018

Accepted: 20 June 2018 